Tạp chi Khoa học và Công nghệ, Số 28, 2017

\title{
ANALYSIS ON THE OPERATION PARAMETERS OF THE NEW CONVERTER TRANSFORMER
}

\author{
THANH NGOC TRAN \\ Faculty of Electrical Technology, Industrial University of Ho Chi Minh City; \\ tranthanhngoc@iuh.edu.vn
}

\begin{abstract}
This paper presents a new converter transformer which is applied in multipulse diode/SCR rectifiers/inverter. Comparison of operational characteristics of a conventional converter transformer and the proposed transformer was studied. Results show that the new converter transformer can not only decrease the grid side current, increase the valve side voltage but also greatly reduce the harmonics of the grid side currents. Simulation results verify the correctness of the theoretical analysis.
\end{abstract}

Keywords. Converter transformers, multipulse rectifiers/inverter, filters.

\section{INTRODUCTION}

The conventional converter transformer $(\mathrm{Y} / \Delta / \mathrm{Y})$ is an important device in 12-pulse diode/SCR converters. It provides a phase displacement between primary side and valve side voltages for harmonic cancellation, supplies a proper valve side voltage, and also makes an electric isolation between the rectifiers and the utility supply. However, because the filters are always placed at the grid side of the transformer, they do not have any influence on the transformer. With or without filters, the operational parameters of the transformer are not changed. [1-17].

Unlike the conventional converter transformer (CCT), the new converter transformer (NCT) with its filters can enhance the operational characteristics $[18,19]$. The new converter transformer with its filters is a special kind of converter transformer whose grid side windings are connected to power grid, the valve side windings are connected to the rectifier, and the common side windings are connected to the filters. Similar to the conventional converter transformers of 12 pulses line commutated converter HVDC with $\mathrm{Y} / \Delta / \mathrm{Y}$ winding connection, the new converter transformer also has an upper and lower bridge which corresponds to $\Delta$ and $\mathrm{Y}$ respectively. In [18], the basic operating principle and wiring scheme are presented. In [19], the characteristic parameters of the new converter transformer are studied in detail.

Different from the already achieved research results in $[18,19]$, in this paper, the mathematical models of the grid side current and valve side voltages of CCT and NCT are established and analyzed, which demonstrates that the NCT with its filters can decrease the grid side current, and increase the valve side voltage. Besides that, the mathematical relationships of harmonic components between the grid side and the valve side of CCT and NCT are also established. The results show that the CCT could greatly reduce the grid side harmonic currents, so could minimize the effect of the harmonics on the transformer. Finally, the detailed simulation results verify the correctness of the theoretical analysis.

\section{THE OPERATIONAL CHARACTERISTICS OF THE CONVENTIONAL CONVERTER TRANSFORMER}

In DC transmission system, the most common way of arranging the thyristor valves is in a 12-pulse group. The thyristor valves are fed by converter transformers connected in $\mathrm{Y} / \Delta$ and $\mathrm{Y} / \mathrm{Y}$ arrangements $(\mathrm{Y} / \Delta / \mathrm{Y})$. The configuration of a 12-pulse converter is shown in Figure 1, where the AC filters are placed at the $\mathrm{AC}$ busbar, $\mathrm{U}_{\text {load }}$ is the phase voltage of the valve side, and $Z_{\mathrm{R}}$ is the impedance of power supply. 


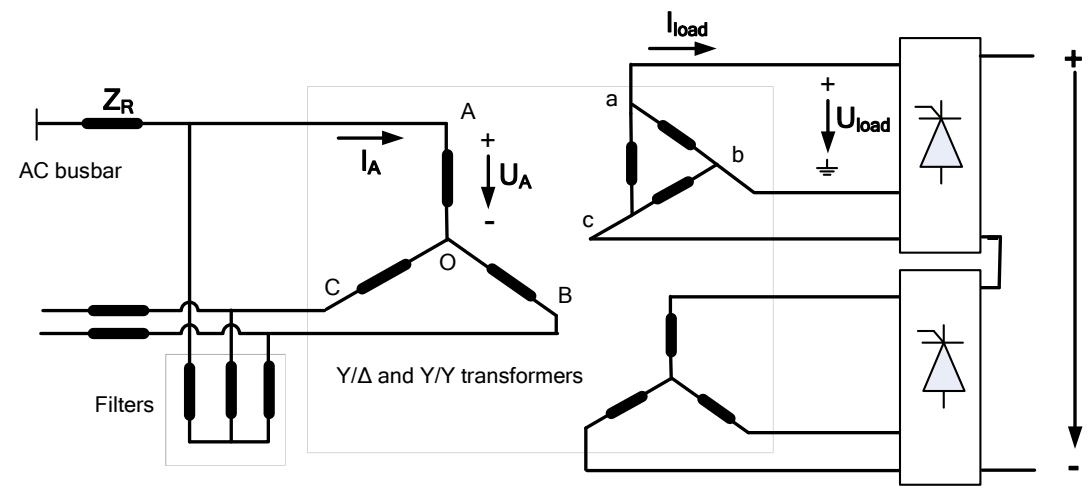

Figure 1. The winding connection scheme of the $\mathrm{Y} / \Delta / \mathrm{Y}$ transformers in the 12-pluse converter

Assume that the voltage ratios of these transformers are equal to $1\left(\mathrm{U}_{\mathrm{AB}} / \mathrm{U}_{\mathrm{ab}}=1\right)$.

\subsection{The grid side current}

Based on Figure 1, the relationship of the currents between the grid side and the valve side for the $\mathrm{Y} / \Delta$ transformer can be expressed by

$$
\dot{I}_{A}=e^{-j 30^{\circ}} \dot{I}_{\text {load }}
$$

\subsection{The valve side voltage}

The relationship of the voltages between the grid side and the valve side is

$$
\dot{U}_{\text {load }}=e^{j 30^{\circ}} \dot{U}_{A}-\dot{I}_{\text {load }} Z_{k}
$$

where $Z_{\mathrm{k}}$ is the short-circuit impedance of the $\mathrm{Y} / \Delta$ transformer.

\subsection{The grid side harmonic current}

The harmonic equivalent diagram of the $\mathrm{Y} / \Delta$ transformer is shown in Figure 2, where the converter load is replaced by a harmonic currents source.

Assume that the impedance of power supply $Z_{R}$ is equal to zero, so the harmonic voltages do not exist at the AC busbar.

$$
\dot{U}_{A}=0
$$

(Note that in a 12-pulse configuration, the 5th, 7th, 17th, and 19th harmonic currents are ignored, and the other harmonics can be suppressed by the AC high-pass filters. So the harmonic voltages at the grid side are also equal to zero)

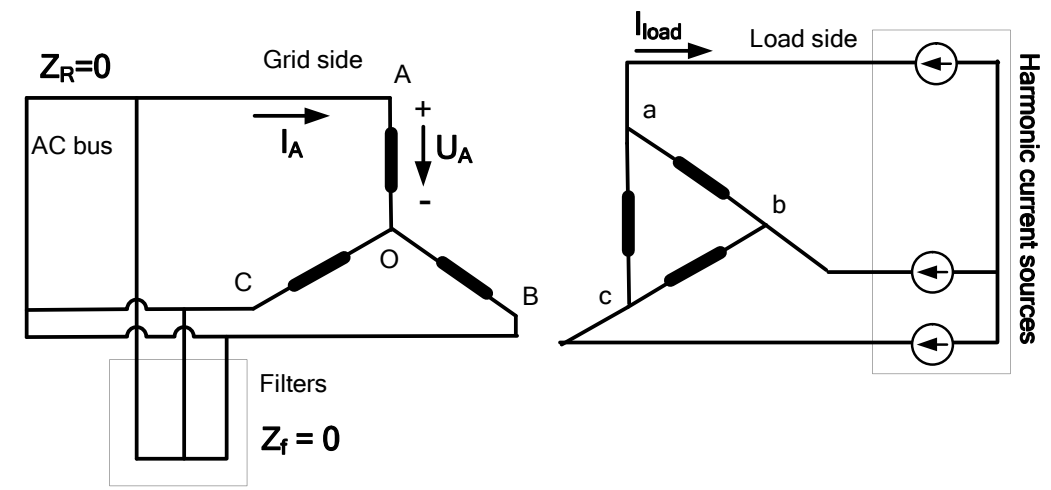

Figure 2. The harmonic equivalent diagram of $\mathrm{Y} / \Delta$ transformer. 
From (1), the relationship of the harmonic currents between the grid side and the valve side can be derived as

$$
\frac{\dot{I}_{A}}{\dot{I}_{\text {load }}}=e^{-j 30^{\circ}}
$$

\section{THE OPERATIONAL CHARACTERISTICS THE NEW CONVERTER TRANSFORMER}

Corresponding to the 12-pulse DC transmission system with the $Y / \Delta / Y$ transformers, Figure 3 shows the the Y/ZF-1/ ZF-2 new converter transformer ( $\mathrm{Z}$ indicates zigzag, F: filters, 1: upper bridge, 2: lower bridge). In Figure 3, the $\mathrm{AC}$ filters are connected to the common windings of the Y/ZF-1/ZF-2 transformers.

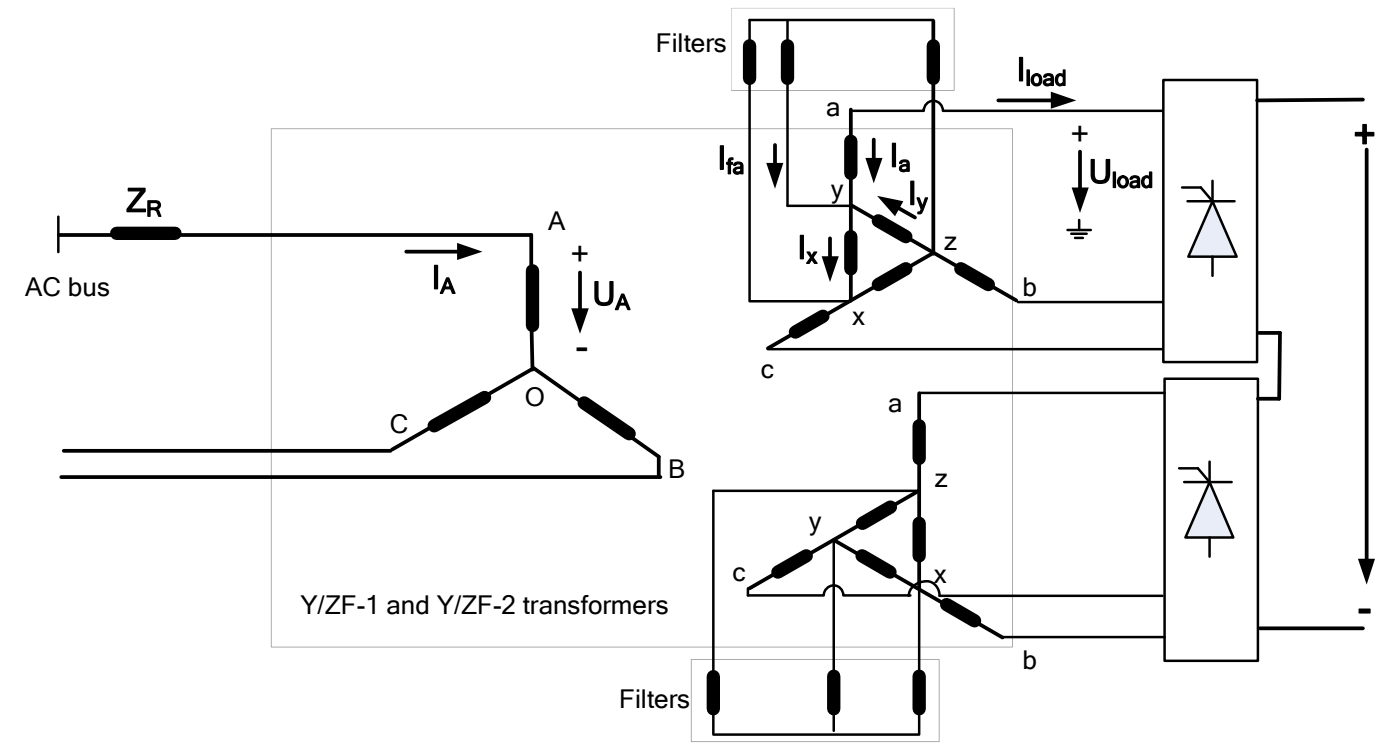

Figure 3. The winding connection scheme of the Y/ZF-1/ ZF-2 transformers in the 12-pluse converter

According to the theory of multi-winding transformer, the mathematical models of the Y/ZF-1 new converter transformers can be written as

$$
\begin{aligned}
& \dot{I}_{A}=-k_{a} \dot{I}_{a}-k_{x} \dot{I}_{x} \\
& \left\{\begin{array}{l}
\dot{U}_{a y}=k_{a} \dot{U}_{A}+k_{a}^{2} Z_{13} \dot{I}_{a}+k_{a} k_{x} Z_{1} \dot{I}_{x} \\
\dot{U}_{y x}=k_{x} \dot{U}_{A}+k_{x}^{2} Z_{12} \dot{I}_{x}+k_{a} k_{x} Z_{1} \dot{I}_{a}
\end{array}\right.
\end{aligned}
$$

where:

$Z_{12}=Z_{1}+Z_{2}^{\prime}, Z_{13}=Z_{1}+Z_{3}^{\prime}, Z_{23}=Z_{2}^{\prime}+Z_{3}^{\prime}, Z_{1}, Z_{2}^{\prime}, Z_{3}^{\prime}$ : are the impedance of the grid side, common side and valve side winding, respectively.

$\dot{I}_{A}, \dot{U}_{A}, Z_{1}, W_{1} ; \dot{I}_{x}, \dot{U}_{y x}, Z_{2}^{\prime}, W_{2} ; \dot{I}_{a}, \dot{U}_{a y}, Z_{3}^{\prime}, W_{3}$ : are the phasor current, phasor voltage, phasor impedance and number of turns of the grid side winding (AO winding); common side winding (yx winding) and valve side winding (ay winding), respectively. 
In this paper, the mathematical model of the new converter transformer is based on voltage ratio which is equal to $1\left(\mathrm{U}_{\mathrm{AB}} / \mathrm{U}_{\mathrm{ab}}=1\right)$, so the values of $\mathrm{k}_{\mathrm{a}}$ and $\mathrm{k}_{\mathrm{x}}$ are [19]:

$$
\begin{aligned}
& k_{a}=W_{3} / W_{1}=0.5176 \\
& k_{x}=W_{2} / W_{1}=\sqrt{3} k_{x}=0.8966
\end{aligned}
$$

\subsection{The grid side current}

The filter current is obtained by Kirchhoff's Current Law

$$
\dot{I}_{f a}=\dot{I}_{x}-\dot{I}_{y}-\dot{I}_{a}=\sqrt{3} e^{j 30^{0}} \dot{I}_{x}-\dot{I}_{a}
$$

The relationship between the voltage and the current of the filters can be expressed by the filter impedance $Z_{f}$

$$
\dot{U}_{y x}=Z_{f}\left(\dot{I}_{f c}-\dot{I}_{f a}\right)=\sqrt{3} e^{j 150^{0}} Z_{f} \dot{I}_{f a}
$$

where $Z_{\mathrm{f}}$ is the equivalent impedance at the fundamental frequency of the filters By substituting (7) into (8), then substituting the result into (6):

$$
k_{x} \dot{U}_{A}+k_{x}^{2} Z_{12} \dot{I}_{x}+k_{a} k_{x} Z_{1} \dot{I}_{a}=\sqrt{3} e^{j 150^{0}} Z_{f}\left(\sqrt{3} e^{j 30^{0}} \dot{I}_{x}-\dot{I}_{a}\right)
$$

From (9), the relationship between the common side winding and valve side winding can be expressed by

$$
\dot{I}_{x}=-\frac{k_{x}}{3 Z_{f}+k_{x}^{2} Z_{12}} \dot{U}_{A}-\frac{\sqrt{3} e^{j 150^{\circ}} Z_{f}+k_{a} k_{x} Z_{1}}{3 Z_{f}+k_{x}^{2} Z_{12}} \dot{I}_{a}
$$

By substituting (10) into (5):

$$
\dot{I}_{A}=\frac{k_{x}^{2}}{3 Z_{f}+k_{x}^{2} Z_{12}} \dot{U}_{A}+\frac{3 e^{-j 15^{0}} Z_{f}+k_{a} k_{x}^{2} Z_{2}^{\prime}}{3 Z_{f}+k_{x}^{2} Z_{12}} \dot{I}_{\text {load }}
$$

Because the equivalent impedance of the filters is much bigger than the impedances of the transformers at the fundamental frequency, the following results can be obtained

$$
\left\{\begin{array}{l}
\left|3 Z_{f}\right|>>k_{x}^{2}\left|Z_{12}\right| \\
\left|3 Z_{f}\right|>>k_{a} k_{x}^{2}\left|Z_{2}^{\prime}\right|
\end{array}\right.
$$

By substituting (12) into (11), the grid side current can be written as

$$
\dot{I}_{A}=j \frac{k_{x}^{2}}{3 X_{f}} \dot{U}_{A}+e^{-j 15^{0}} \dot{I}_{\text {load }}
$$

where $\mathrm{X}_{\mathrm{f}}=1 /(\mathrm{wC})$ is the equivalent capacitive reactance of the filters.

\subsection{The valve side voltage}

Also, from Figure 3:

$$
\dot{U}_{a b}=\dot{U}_{a y}-\dot{U}_{z y}-\dot{U}_{b z}=\sqrt{3} e^{j 30^{0}} \dot{U}_{a y}-e^{-j 120^{0}} \dot{U}_{y x}
$$

By substituting (6) into (14):

$$
\begin{aligned}
& \dot{U}_{a b}=\dot{U}_{A}\left(\sqrt{3} e^{j 30^{0}} k_{a}-e^{-j 120^{0}} k_{x}\right)+\dot{I}_{a}\left(\sqrt{3} e^{j 30^{0}} k_{a}^{2} Z_{13}-e^{-j 120^{0}} k_{a} k_{x} Z_{1}\right) \\
& +\dot{I}_{x}\left(\sqrt{3} e^{j 30^{0}} k_{a} k_{x} Z_{1}-e^{-j 120^{0}} k_{x}^{2} Z_{12}\right)
\end{aligned}
$$

By substituting (10) into (15): 


$$
\dot{U}_{a b}=\sqrt{3} e^{j 30^{0}} \frac{e^{j 15^{0}} 3 Z_{f}+k_{a} k_{x}^{2} Z_{2}^{\prime}}{3 Z_{f}+k_{x}^{2} Z_{12}} \dot{U}_{A}+\sqrt{3} e^{j 30^{0}} \frac{3 Z_{f} Z_{k}+k_{a}^{2} k_{x}^{2}\left(Z_{12} Z_{13}-Z_{1}^{2}\right)}{3 Z_{f}+k_{x}^{2} Z_{12}} \dot{I}_{a}
$$

where $Z_{\mathrm{k}}$ is the basic short-circuit impedance of the $\mathrm{Y} / \mathrm{ZF}-1 / \mathrm{ZF}-2$ new converter transformer

$$
Z_{k}=k_{a}^{2}\left(Z_{12}+Z_{13}+\sqrt{3} Z_{1}\right)
$$

By using the phase load voltage $\mathrm{U}_{\text {load }}$ and the load current $\mathrm{I}_{\text {load }}$, (16) can be written as

$$
\dot{U}_{\text {load }}=\frac{e^{j 15^{0}} 3 Z_{f}+k_{a} k_{x}^{2} Z_{2}^{\prime}}{3 Z_{f}+k_{x}^{2} Z_{12}} \dot{U}_{A}-\frac{3 Z_{f} Z_{k}+k_{a}^{2} k_{x}^{2}\left(Z_{12} Z_{13}-Z_{1}^{2}\right)}{3 Z_{f}+k_{x}^{2} Z_{12}} \dot{I}_{\text {load }}
$$

The relationships of the filters impedance and the transformer impedances can be obtained

$$
\left\{\begin{array}{l}
\left|3 Z_{f}\right|>>k_{a} k_{x}^{2}\left|Z_{2}^{\prime}\right| \\
\left|3 Z_{f} Z_{k}\right|>>k_{a}^{2} k_{x}^{2}\left|Z_{12} Z_{13}-Z_{1}^{2}\right|
\end{array}\right.
$$

By substituting (18) into (17):

$$
\dot{U}_{\text {load }}=\frac{e^{j 15^{0}} 3 Z_{f}}{3 Z_{f}+k_{x}^{2} Z_{12}} \dot{U}_{A}-\frac{3 Z_{f} Z_{k}}{3 Z_{f}+k_{x}^{2} Z_{12}} \dot{I}_{\text {load }}
$$

So the load voltages can be expressed as

$$
\dot{U}_{\text {load }}=k_{0}\left(e^{j 15^{0}} \dot{U}_{A}-Z_{k} \dot{I}_{\text {load }}\right)
$$

where $\mathrm{k}_{0}$ is the voltage increase factor

$$
k_{0}=\frac{3 Z_{f}}{3 Z_{f}+k_{x}^{2} Z_{12}}
$$

\subsection{The grid side harmonic current}

The harmonic equivalent diagram of the Y/ZF-1 transformer is shown in Figure 4, where the converter load is replaced by a harmonic currents source

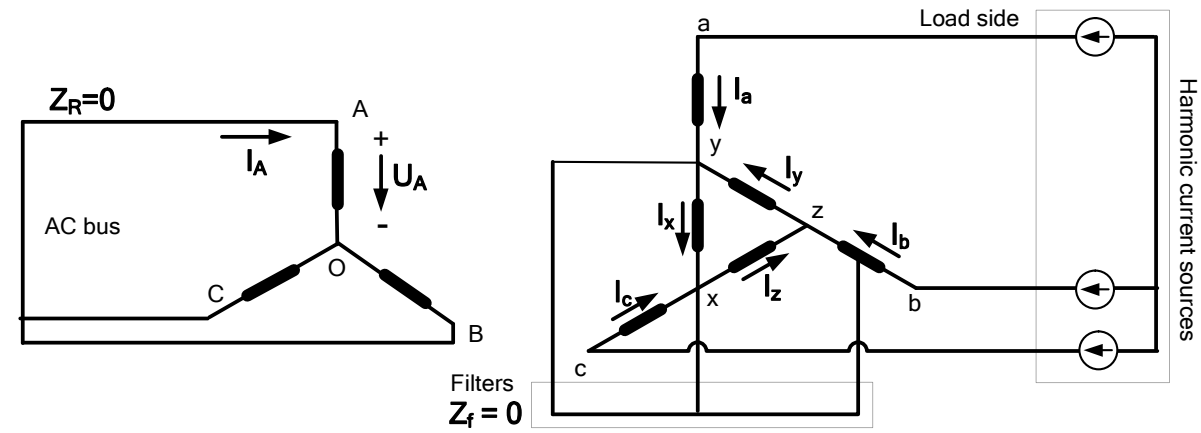

Figure 4. The harmonic equivalent diagram of $\mathrm{Y} / \mathrm{ZF}-1$ transformer

Assume that the impedance of power supply $Z_{R}$ is equal to zero, so the harmonic voltages do not exist at the AC busbar

$$
\dot{U}_{A}=0
$$

Because the common winding of Y/ZF-1 transformer is connected to the filters, so the common winding is short-circuited at the tuned frequencies

$$
\dot{U}_{\mathrm{yx}}=\dot{U}_{\mathrm{zy}}=\dot{U}_{x z}=0
$$

By substituting (22) and (23) into (6) 


$$
\begin{aligned}
& k_{x}^{2} Z_{12} \dot{I}_{x}+k_{a} k_{x} Z_{1} \dot{I}_{a}=0 \\
& \Rightarrow \dot{I}_{x}=-\frac{k_{a} Z_{1}}{k_{x} Z_{12}} \dot{I}_{a}
\end{aligned}
$$

By substituting (24) into (5), the relationship of the harmonic currents between the grid side and valve side can be derived as

$$
\frac{\dot{I}_{A}}{\dot{I}_{a}}=\frac{-k_{a} Z_{2}^{\prime}}{Z_{12}}
$$

\section{ANALYSIS OF THE OPERATIONAL CHARACTERISTICS OF THE CONVENTIONAL AND NEW CONVERTER TRANSFORMERS}

Table 1 shows the reactive power compensation characteristics for the $\mathrm{Y} / \Delta$ conventional conveter transformer and the Y/ZF-1 new converter transformer. In Table 1, the operational parameters of the $\mathrm{Y} / \Delta$ transformer are obtained from (1), (2) and (4); and the operational parameters of the Y/ZF-1 transformer are obtained from (13), (20), (25).

Table 1. The operational parameters of converter transformers

\begin{tabular}{|c|c|c|}
\hline \multirow{2}{*}{ Operational parameters } & Y/A & Yransformers \\
\cline { 2 - 3 } & 30 & 15 \\
\hline Secondary shifting angle & $e^{-j 30^{\circ}} \dot{I}_{\text {load }}$ & $j \frac{k_{x}^{2}}{3 X_{f}} \dot{U}_{A}+e^{-j 15^{0}} \dot{I}_{\text {load }}$ \\
\hline Grid side current $\dot{I}_{A}$ & $e^{j 30^{\circ} \dot{U}_{A}-\dot{I}_{\text {load }} Z_{k}}$ & $k_{0}\left(e^{j 15^{0}} \dot{U}_{A}-Z_{k} \dot{I}_{\text {load }}\right)$ \\
\hline Valve side voltage $\dot{U}_{\text {load }}$ & 1 & $\frac{k_{a} Z_{2}^{\prime}}{Z_{12}}$ \\
\hline $\begin{array}{c}\text { The ratio of harmonic } \\
\text { components }\left|\dot{I}_{A} / \dot{I}_{\text {load }}\right|\end{array}$ & &
\end{tabular}

Note:

Because the mathematical models of the $\mathrm{Y} / \Delta$ and $\mathrm{Y} / \mathrm{ZF}-1$ transformers are established based on the voltage ratios equal to 1 , namely, so in Table 1 , the values of the load current which is referred to grid side and the value of the grid side voltage which is referred to valve side do not contain the voltage ratio of the transformer.

In a similar manner, the mathematical model of the lower bridge ( $\mathrm{Y} / \mathrm{Y}$ and $\mathrm{Y} / \mathrm{ZF}-2$ transformers) can be obtained and have the same results with Table 1.

\subsection{The grid side current}

The vector diagrams of the grid side current for the $\mathrm{Y} / \Delta$ and $\mathrm{Y} / \mathrm{ZF}-1$ transformers are shown in Figure 5, in which the mathematical equations of the grid side currents are obtained from Table 1. 


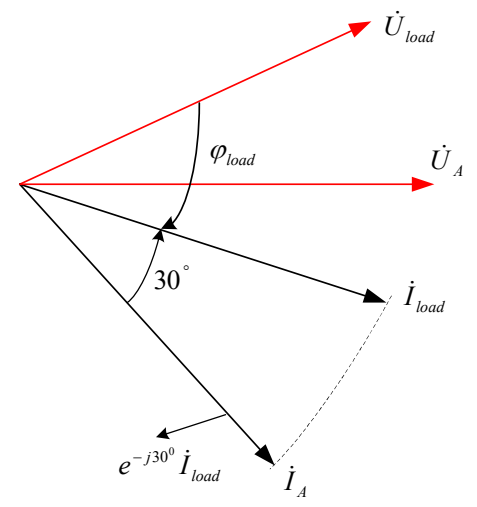

(a) $Y / \Delta$

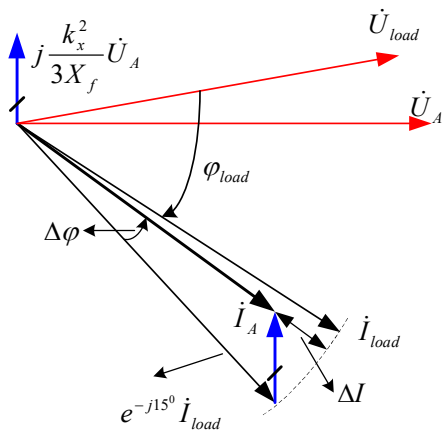

(b) Y/ZF-1

Figure 5. The vector diagrams of the grid side currents

For the $\mathrm{Y} / \Delta$ transformer, the magnitudes of the grid side currents are equal to the valve side currents; the filters placed in front of the transformer do not have any effect on the grid side current.

For the Y/ZF-1 transformer, due to existence of the compensating current which leads the grid side voltage by $90^{\circ}$, the magnitude of the grid side current is decreased by $\Delta \mathrm{I}$. So the $\mathrm{Y} / \mathrm{ZF}-1$ transformer with filters can decrease the grid side current.

\subsection{The valve side voltage}

Figure 6 shows the curves of the voltage increase factors versus the ratio between filters power and transformer power. In Figure 6, the mathematical equations of the voltage increase factors are obtained from Table 1, and noting that the voltage increase factor for the $\mathrm{Y} / \Delta$ is equal to 1.

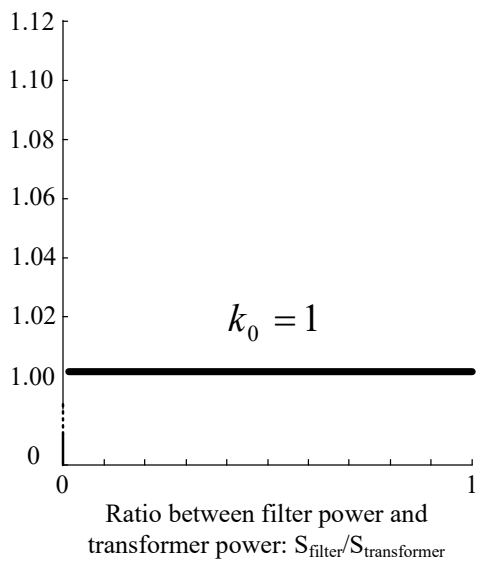

(a) $Y / \Delta$

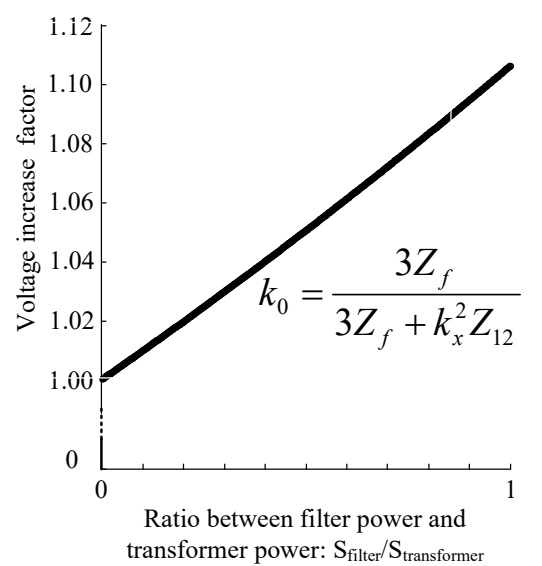

(b) $Y / Z F-1$

Figure 6. The curve of voltage increase factor $\mathrm{k}_{0}$

For the $\mathrm{Y} / \Delta$ transformers, the load voltage equals to no-load voltage minus voltage drop, the voltage drop is equal to the load current multiplied by the short-circuit impedance. So the load voltage does not depend on the filters.

For the Y/ZF-1 transformer, the magnitude of the load voltage is proportion to the voltage increase factor $\mathrm{k}_{0}$, when power of the filters is increased, the factor $\mathrm{k}_{0}$ is increased. So the Y/ZF-1 transformer with filters can increase the load voltage. 


\subsection{The grid side harmonic current}

Assume that the load harmonic currents $\dot{I}_{\text {load }}$ are the same for the Y/A and Y/ZF-1 transformers. For the purpose of suppressing the harmonic components in the Y/ZF-1/ZF-2 new converter transformer, the impedance of the common winding of this transformer is designed much smaller than the impedance of the grid side winding, namely, $Z_{2}^{\prime}<<Z_{1}$.

Based on analyzing Table 1, the results show that:

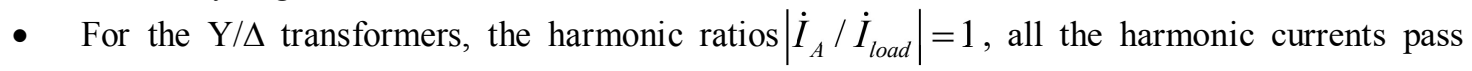
through the load and grid side windings of the $\mathrm{Y} / \Delta$ transformers, the filters do not have any effect on the transformers.

- Whereas, for the Y/ZF-1 transformer, the ratio $\left|\dot{I}_{A} / \dot{I}_{\text {load }}\right|=k_{a} Z_{2}^{\prime} / Z_{12} \approx 0$ because of $Z_{2}^{\prime}<<Z_{1}$, so the Y/ZF-1 transformer can greatly reduce the harmonic currents on the grid side.

\section{THE SIMULATION RESULTS}

\subsection{Simulation Model}

To verify the operational characteristics of the CCT and NCT, a 12-pulse DC transmission system simulink model was designed. Figure 7 shows the simulation scheme of the 12-pulse DC transmission system. The rated values of power, voltage and current at the DC side are $100 \mathrm{~kW}, 1000 \mathrm{~V}$ and $100 \mathrm{~A}$, respectively.

At the rectifier side, the $400 \mathrm{~V} / 400 \mathrm{~V}$ rated voltage new converter transformers are used; the controllers of the rectifiers adjust the DC current; the filters include single tuned $5^{\text {th }}, 7^{\text {th }}, 11^{\text {th }}, 13^{\text {th }}$ order filters. At the converter side, the $400 \mathrm{~V} / 400 \mathrm{~V}$ rated voltage conventional converter transformers are used; the controllers of the converters adjust the DC voltage; the filters include single tuned $11^{\text {th }}, 13^{\text {th }}$ order filters.

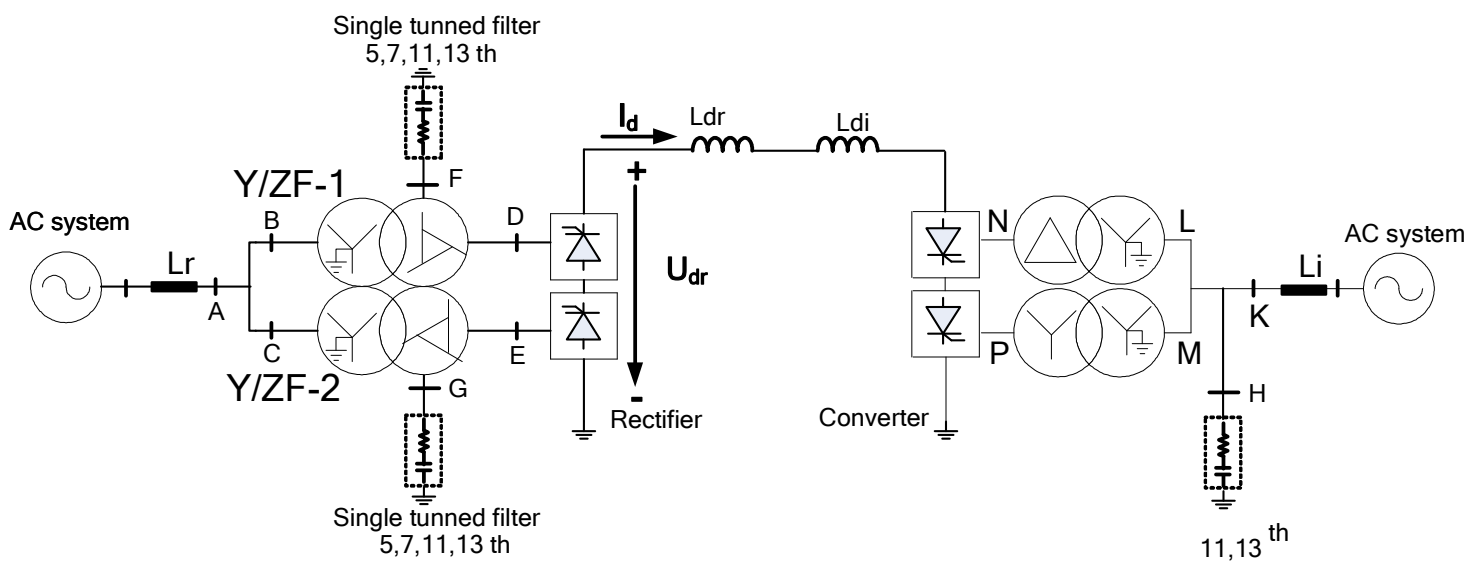

Figure 7. The simulation diagram of the DC transmission system

\subsection{The Simulation Results}

Table 2 shows the operational parameters of simulation results of the $Y / \Delta / Y$ conventional converter transformers and $\mathrm{Y} / \mathrm{ZF}-1 / \mathrm{ZF}-2$ new converter transformers. 
Table 2. The operational parameters of converter transformers

\begin{tabular}{|c|c|c|c|c|c|c|c|c|}
\hline \multirow{3}{*}{ Parameters } & \multicolumn{4}{|c|}{ Upper bridge } & \multicolumn{4}{|c|}{ Lower bridge } \\
\hline & \multicolumn{2}{|c|}{$\mathrm{Y} / \Delta$} & \multicolumn{2}{|c|}{$\mathrm{Y} / \mathrm{ZF}-1$} & \multicolumn{2}{|c|}{$\mathrm{Y} / \mathrm{Y}$} & \multicolumn{2}{|c|}{$\mathrm{Y} / \mathrm{ZF}-2$} \\
\hline & L point & $\mathrm{N}$ point & B point & D point & M point & P point & C point & E point \\
\hline Current-A & $\begin{array}{c}41.42 \\
\angle-133.68^{0}\end{array}$ & $\begin{array}{c}40.69 \\
\angle-105.55^{\circ}\end{array}$ & $\begin{array}{c}33.87 \\
\angle-25.25^{0}\end{array}$ & $\begin{array}{c}40.82 \\
\angle-30.35^{0}\end{array}$ & $\begin{array}{c}41.48 \\
\angle-133.38^{0}\end{array}$ & $\begin{array}{c}40.71 \\
\angle-135.36^{0}\end{array}$ & $\begin{array}{c}33.90 \\
\angle-25.31^{0}\end{array}$ & $\begin{array}{c}40.70 \\
\angle-60.50\end{array}$ \\
\hline Voltage-V & $\begin{array}{c}410.10 \\
\angle 29.90^{\circ} \\
\end{array}$ & $\begin{array}{c}381.36 \\
\angle 65.28^{0} \\
\end{array}$ & $\begin{array}{c}409.41 \\
\angle 27.22^{0} \\
\end{array}$ & $\begin{array}{c}392.14 \\
\angle 38.61^{0} \\
\end{array}$ & $\begin{array}{c}410.10 \\
\angle 29.90^{\circ} \\
\end{array}$ & $\begin{array}{c}382.76 \\
\angle 35.20^{\circ} \\
\end{array}$ & $\begin{array}{c}409.41 \\
\angle 27.22^{0} \\
\end{array}$ & $\begin{array}{l}392.03 \\
\angle 8.62^{0} \\
\end{array}$ \\
\hline THD I- $\%$ & 26.03 & 26.65 & 5.80 & 30.12 & 26.15 & 26.70 & 5.80 & 30.33 \\
\hline Firing angle $\alpha$ & \multicolumn{2}{|c|}{$130.32^{0}$} & \multicolumn{2}{|c|}{$43.61^{0}$} & \multicolumn{2}{|c|}{$130.32^{0}$} & \multicolumn{2}{|c|}{$43.61^{0}$} \\
\hline
\end{tabular}

Based on comparing the operational parameters of CCT and NCT of the upper bridge (the same results for the lower bridge), the results show that:

- $\quad$ NCT can decrease the grid side current (41.42 A for $\mathrm{Y} / \Delta$ and 33.87 A for Y/ZF-1).

- $\quad \mathrm{NCT}$ can increase the valve side voltage (381.36 V for $\mathrm{Y} / \Delta$ and $392.14 \mathrm{~V}$ for $\mathrm{Y} / \mathrm{ZF}-1)$.

Figure 8 and Figure 9 show the waves and its fast Fourier transform of the valve side currents, grid side currents of the CCT and NCT, respectively.
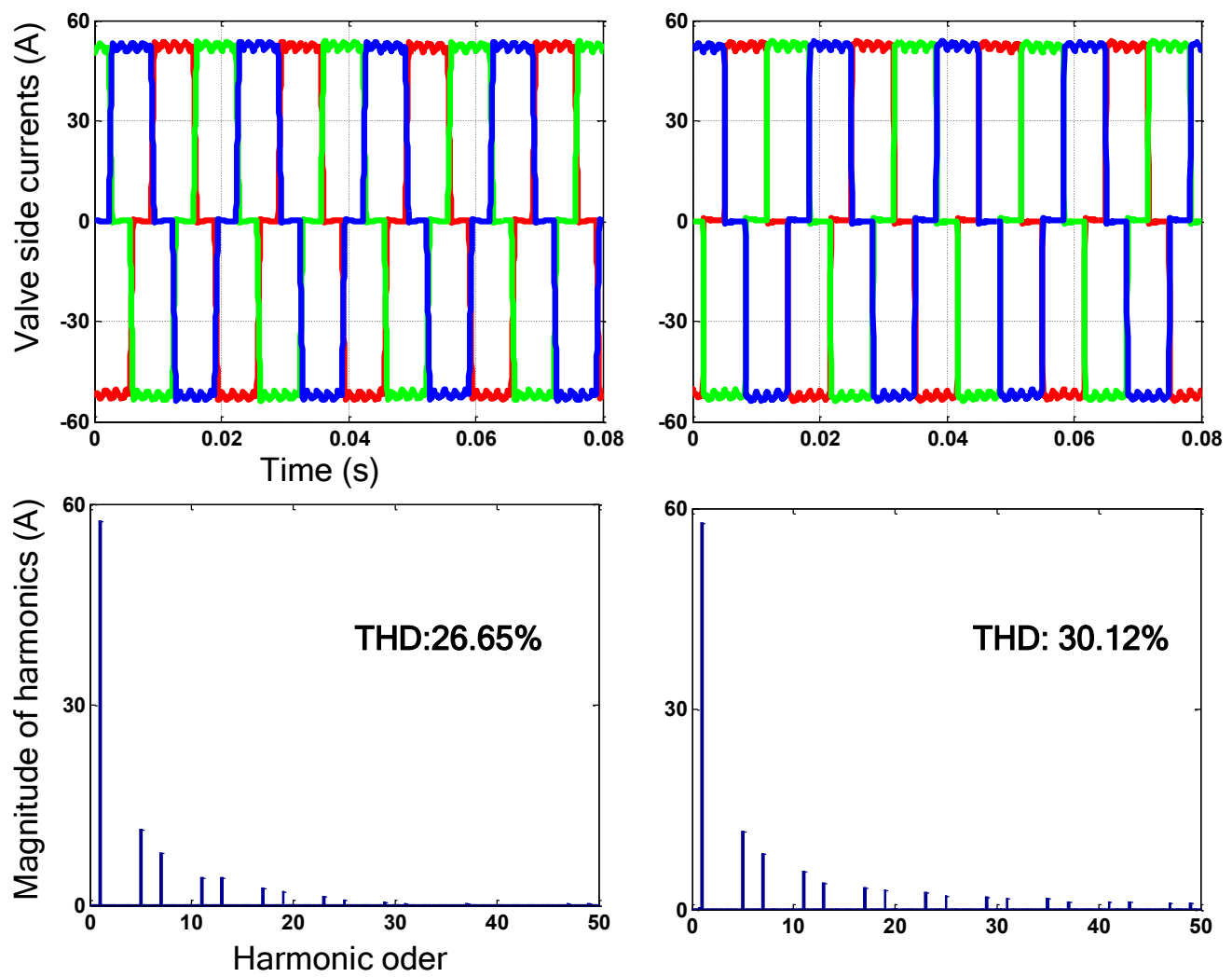

(a) CCT

(b) NCT

Figure 8. The valve side currents and its fast Fourier transform 

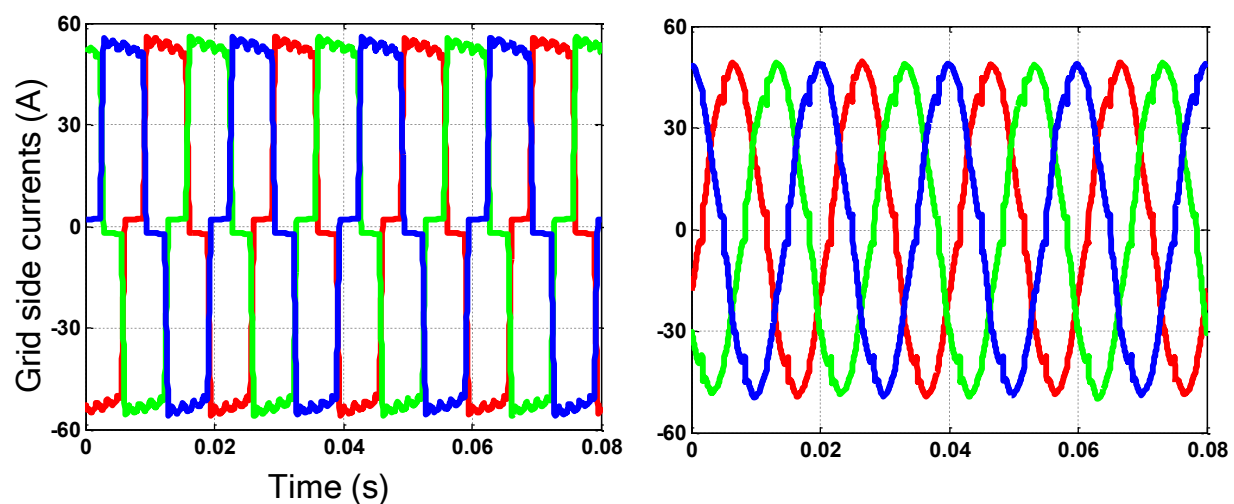

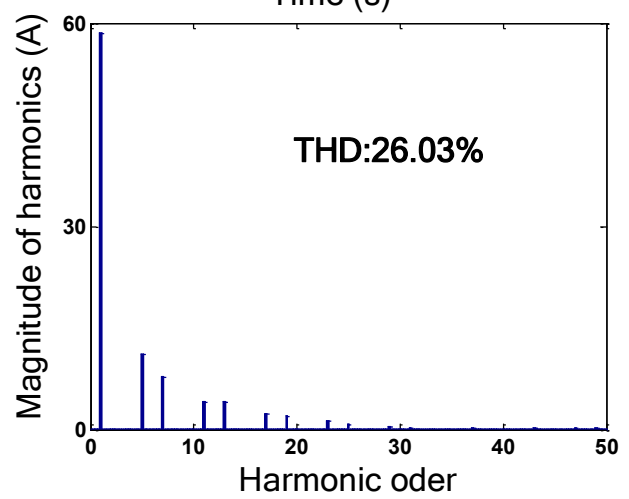

(a) CCT

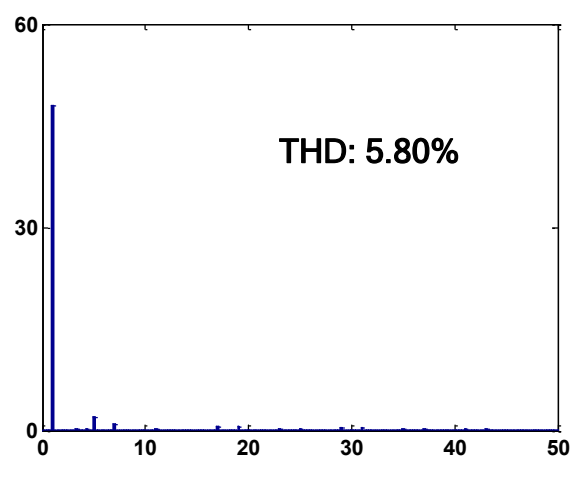

(b) NCT

Figure 9. The grid side currents and its fast Fourier transform

Based on analyzing the Figure 8 and Figure 9, the results show that:

- The valve side currents: The valve side harmonic currents are almost the same for the CCT and NCT, the waves of load currents are much distorted; THD is approximately $26 \%$ for $\mathrm{Y} / \triangle \mathrm{CCT}$ and $30 \%$ for $\mathrm{Y} / \mathrm{ZF}-1 \mathrm{NCT}$.

- Grid side currents: The waveforms of the grid side current of CCT are much distorted; THD is $26.03 \%$; whereas the waveforms of NCT are clearly sine-shaped, THD is $5.8 \%$.

Note that under the grid side voltage is not changed. With NCT, the voltage of the valve side is increased; hence the delay angle of the 12 pulses converter in HVDC also is increased to maintain the DC load constant. So that is the reason why the THD of the valve side currents of NCT is higher than CCT.

\section{CONCLUSIONS}

This paper presents a new converter transformer which can be applied for multipulse converter. The mathematical models of the conventional converter transformer and the new converter transformer are established, which have made it possible to analyze the operational parameters of the transformers. The results show that the new converter transformer can improve the operational parameters, such as decreasing the grid side current, increasing the valve side voltage and can be greatly decrease the harmonic components in the grid side currents. The simulation results are recorded to verify the theoretical analysis 


\section{REFERENCES}

[1] B. Wu, High-Power Converters and AC Drives. Piscataway, NJ: IEEE. Press, 2006.

[2] Edward W. Kimbark, Direct Current Transmission Volume I, John Wiley \& Sons, Inc., 1971.

[3] Vijay K. Sood, HVDC and FACTS controllers. Kluwer, 2004.

[4] J. Arrillaga, High Voltage Direct Current Transmission, 2nd Edition. IEE Power Engineering Series, 1998.

[5] M. Szechtman, T. Wess, and C. V. Thio, "A benchmark model for HVDC system studies," in Proc. IEEE Int. Conf. AC and DC Power Transmission, Sep. 17-20, 1991, pp. 374-378.

[6] M. P. Bahrman and B. K. Johnson, "The ABCs of HVDC transmission technologies," IEEE Power Energy Mag., vol. 5, pp. 32-44, Mar.-Apr 2007.

[7] F. Nozari and H. S. Patel, "Power electronics in electric utilities: HVDC power transmission systems," Proc. IEEE, vol. 76, pp. 521-532, Apr. 1988.

[8] Hualei Wang; Redfern, M. A, "The advantages and disadvantages of using HVDC to interconnect AC networks," Universities Power Engineering Conference (UPEC), 2010 45th International, vol., no., pp.1-5.

[9] L. Pierce, "Transformer design and application considerations for nonsinusoidal load currents," IEEE Trans. Ind. Appl., vol. 32, no. 3, pp. 633-645, May/Jun. 1996.

[10] J. A. C. Forrest, "Harmonic load losses in hvdc converter transformers," IEEE Trans. Power Delivery, vol. 6, no. 1, pp. 153-157, Jan. 1991.

[11] Bahrman, M.P., "HVDC transmission overview," Transmission and Distribution Conference and Exposition, 2008, vol., no., pp.1-7.

[12] J. Setreus and L. Bertling, "Introduction to HVDC Technology for Reliable Electrical Power Systems," in Proc. Int. Conf. Probabilistic Methods Applied to Power Systems, 2008. PMAPS '08, vol., no., pp.1-8.

[13] S. Cole and R.Belmans, "Transmission of bulk power," Industrial Electronics Magazine, IEEE, vol.3, no.3, pp.19-24, Sept. 2009.

[14] B. S. Ram, J. A. C. Forrest, and G. W. Swift. "Effect of harmonics on converter transformer load losses," IEEE Trans. Power Delivery, vol. 3, no. 3, pp. 1059-1066, July 1988.

[15] L. Hu and R. Yacamini, "Harmonic transfer through converters and HVDC links," IEEE Trans. Power Electronics, vol. 7, no. 3, pp. 514-524, July 1992.

[16] K. Sadek and M. Pereira, "Harmonic transfer in HVDC systems under unbalanced conditions," IEEE Trans. Power Systems, vol. 14, no. 4, pp. 1934-1939, Nov. 1999.

[17] P. Riedel, "Harmonic voltage and current transfer, and AC- and DC-side impedances of HVDC converters," IEEE Trans. Power Del., vol. 20, no. 3, pp. 2095-2099, Jul. 2005.

[18] L. F. Luo, Y. Li, J. Z. Xu, J. Li, B. Hu, and F. S. Liu, "A new converter transformer and a corresponding inductive filtering method for HVDC transmission system," IEEE Trans. Power Del., vol. 23, no. 3, pp. 14261431, Jul. 2008.

[19] Y. Li, L. F. Luo, C. Rehtanz, K. Nakamura, J. Z. Xu, and F. S. Liu, "Study on characteristic parameters of a new converter transformer for HVDC systems," IEEE Trans. Power Del., vol. 24, no. 4, pp. 2125- 2131, Oct. 2009. 
[20] L. Luo, Y. Li, K. Nakamura, G. Krost, J. Li, J. Xu and F. Liu, "Harmonic characteristics of new HVDC transmission system based on new converter transformer," in 3rd International Conference on Deregulation and Restructuring and Power Technologies, DRPT 2008, 2008, pp. 1868-1872.

[21] L. Luo, Y. Li, J. Li, J. Xu, and F. Liu, "Transient simulation of the AC/DC system based on the new-type converter transformer,” in Proc. Int. Conf. Power System Technology, Oct. 2006, pp. 1-5.

[22] L. Luo, J. Xu, J. Li, Y. Li, and F. Liu, "A novel method of harmonic suppression in the AC/DC transmission system based on novel converter transformer," in Proc. Int. Conf. Power System Technology, Oct. 2006, pp. 1-6.

\section{PHÂN TÍCH ĐẶC TÍNH VẬN HÀNH CỦA MÁY BIẾN ÁP BIẾN ĐỔI MỚI}

Tóm tắt. Bài báo giới thiệu một mô hình máy biến áp biến đổi mới được áp dụng trong bộ chỉnh lưu/nghịch lưu diode/SCR đa xung. So sánh đặc tính vận hành của máy biến áp biến đổi kiểu truyền thống với đặc tính vận hành của máy biến áp biến đổi kiểu mới đã được nghiên cứu. Kết quả chỉ ra rằng máy biến áp biến đổi kiểu mới không những có thể làm giảm dòng điện phía lưới, làm tăng điện áp phía tải mà còn có thể triệt tiêu đáng kể thành phần sóng hài của dòng điện phía lưới của máy biến áp. Các kết quả mô phỏng đưự̛c thực hiện đã chứng minh sự chính xác của các phân tích lý thuyết.

Từ khóa. Máy biến áp biến đổi, bộ chỉnh lưu/ nghịch lưu đa xung, bộ lọc.

Ngày nhận bài: 11/07/2017

Ngày chấp nhận đăng: 14/09/2017 